\title{
The role of parent-child relationship, school climate, happiness, and empathy to predict cyberbullying behavior
}

\author{
Triantoro Safaria, Hadi Suyono
}

Faculty of Psychology, Universitas Ahmad Dahlan, Indonesia

\begin{tabular}{|c|c|}
\hline Article Info & ABSTRACT \\
\hline Article history: & The lack of research on cyberbullying among Indonesian adolescents has \\
\hline Received Aug 26, 2019 & $\begin{array}{l}\text { become one of the critical arguments of this research. This study aimed to } \\
\text { discover the factors that contribute to cyberbullying. This study took samples }\end{array}$ \\
\hline Revised Feb 11, 2020 & of students from three schools. The sample was 112 junior to senior high \\
\hline Accepted Jun 20, 2020 & $\begin{array}{l}\text { school students. The findings of this study indicate that school climate, } \\
\text { parent-child relationship, and empathy have a significant role that encourages }\end{array}$ \\
\hline
\end{tabular}

Cyberbullying perpetrators

Empathy

Happiness

Parent-child relationship

School climate

This is an open access article under the CC BY-SA license.

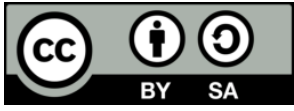

\section{Corresponding Author:}

Triantoro Safaria,

Faculty of Psychology,

Universitas Ahmad Dahlan,

Jalan Kapas no. 9, Semaki, Yogyakarta, Indonesia.

Email: triantoro.safaria@psy.uad.ac.id

\section{INTRODUCTION}

Cyberbullying is an intentional aggressive act aimed to insult and hurt others, which is done repeatedly by individuals or groups through the internet or digital social media [1-4]. Recent studies show that cyberbullying victimization relates to alcoholism, marijuana usage, and frequent unhealthy sexual behavior. Furthermore, the combination of physical bullying and cyberbullying has a more severe impact on the emergence of deviant risk behavior [5]. Cyberbullying victimization also correlates with suicide ideas or suicidal behavior [6], and symptoms of depression.

Previous research found several adverse effects of cyberbullying. Cyberbullying victims show anger, decreased academic achievement, psychological problems, and hopelessness - allowing them to become cyberbullied [7-11]. Data reported that, of 265 female students involved in cyberbullying as either perpetrators or victims, showed high levels of depression and alcohol use [12]. Many victims of cyberbullying show an increase in severe social anxiety [13]. Akbulut \& Cuhadar [14] and Schenk \& Fremouw [10] report victims of cyberbullying showing sadness, crying, feeling embarrassed, skipping school, becoming depressed, experiencing insomnia, and the worst impact being having suicidal ideas. While Spears [15] report that some victims of cyberbullying experience constant fear of their safety. The impact of cyberbullying must not be underestimated, so it requires more profound research to understand and solve this phenomenon.

Regarding the prevalence rate, recent studies reveal cyberbullying to be quite common in the school-age population globally. Various studies across the world have explored this phenomenon, such as in Canada [16], UK and Ireland [17], and USA [18]. Additionally, it also occurred in Latin American 
countries [19] Spain [20, 21]. Asian countries like Korea [22]; Israel [23]; Hong Kong China [24]; Japan [25], and Indonesia [1,3]. The prevalence of cyberbullying victimization and perpetration can vary with regard to demographic backgrounds (e.g., gender, age, race/ethnicity, sexuality, education, disability), individuals (e.g., experiences with traditional bullying), academic achievement, school climate, personality, weight status, technology use), family, and peer [2,4]. Regardless of this variation, however, cyberbullying is now a typical aggressive behavior found in interpersonal relationships in today's modern society. Thus, it becomes an important topic to be explored in moredepth, especially in Indonesia because there is a lacking study conducted about it. Therefore, this study aims to examine whether parent-child relationships, happiness, empathy, and school climate could predict cyberbullying among adolescents.

Previous research shows that an unhealthy family atmosphere has a negative impact on children's emotional, social, and personality development [26]. Negative family environment is characterized by lack of love, lack of social and emotional support, closed and abusive communication patterns, conflicts, limited parental availability, permissive parenting, coercive punishment and authoritarianism, encouragement for vulnerable children to experience being bullied or involved in acts of violence [27, 28]. Other studies also confirm that children who are exposed to marital conflict and families in their homes tend to engage in antisocial and violent behaviors). Children from these broken families tend to develop aggressive behavior [29] due to the frustration that they feel towards their families, which later ventures into their peers in the context of face to face aggression and cyberaggression [30]. An uncomfortable family atmosphere causes children to spend their timewith cyber activities as a way to escape the conflict in their families [31], increasing their likelihood to be involved in cyberaggression behavior to intimidate others. These aggressive teens tend to have hostile relationships with parents and find it challenging to develop adherence to existing social rules, encouraging the process of transference of aggressive behavior in the family to the school or cyberspace environment even more [32]. For this reason, the parent-child relationship role in cyberbullying behavior needs to be explored more, particularly in the context of Indonesia.

School climate is the social atmosphere of the learning environment where students grow and develop. The positive school climate has multiple aspects, such as clear rules, fair discipline, class management, empathic communication, and healthy interpersonal relationships, including a safe school environment [33-35]. Schools with a positive school climate can influence the formation of better teacherstudent relationships; decrease the quantity of student delinquency, decrease victimization violence, increase teacher self-efficacy, increase academic performance, decrease bullying and ethnic discrimination/racial discrimination [34, 36-39]

School climate can also influence student academic achievement [40]. Exposure to school violence reduces student attendance, lowers test scores, increases misconduct, and reduces the likelihood of students graduating high school and being accepted in college [41, 42]. Research shows that being a victim of cyberbullying in schools is associated with an increased in poor student behavior and decreasededucational values [43] Even just witnessing violence occurring in schools results in consequences of students showing negative behavior, negative attitudes about schooling, and decreased attendance at school [44] Exposure to violance in schools, such as intimidation, or bullying is negatively correlated with student achievement and associated with more severe school violence [45-47]. Positive school climate can isolate students from a violent environment, turning it into a safe place to learn and develop [43]. In this context, research needs to explore the role of school climate on cyberbullying behavior in Indonesia.

Happiness is highly sought after by individuals and is closely related to life satisfaction, the meaningfulness of life, and psychological health. Happiness is also associated with an increase in positive emotional emotions and decrease in negative emotions [48]. Some studies show that happy individuals are more passionate, vibrant, energetic, and enthusiastic in comparison to unhappy individuals [48, 49]. Happiness also affects the increase in daily positive activities of individuals. Research on prosocialoffline behavior shows that happiness correlates with prosocial behavior; namely that happy individuals are more likely to show prosocial behavior [50-52]. Erreygers's research [53] found that individual happiness can spill over and cross over on prosocial behavior online; meaning that happy individuals tend to avoid antisocial behavior in cyberspace.

Several previous studies have confirmed the significant relationship between cyberbullying and happiness. Uusitalo-Malmivaara and Lehto [54] found that cyberbullying victims have increased symptoms of depression and a decreased level of happiness. Meanwhile, Ali Padir, Eroglu, \& Caliskan [55] found a significant negative correlation between happiness and cyberbullying victimization. Navarro [56] found a decrease in subjective well-being in both perpetrators and victims. Furthermore, spillover-crossover research shows that positive moods in one context can spill over to another context, and even cross over from one person to another [57-59]. This theory asserts that happiness can spread in one context to another, as well as spread from one person to the next. Happy individuals tend to spread happiness to those around 
them, including in cyberspace. This causes them to avoid aggressive behavior in both the real world and cyberspace.

Empathy is the ability to understand others $[60,61]$. It is defined as "an emotional response that stems from another person's emotional state or condition, which is highly similar to what the other individual would be expected to feel"[62]. Empathy is also a form of social awareness, where individuals share emotional experiences with others at an affective and cognitive level [63]. Affective empathy refers to the right emotional reaction in responding to the emotions of others [64]. In another sense, individuals can "catch" or "experience" the emotional state of others. Affective empathy is therefore essential in determining individual altruistic behavior [65, 66]. Meanwhile, cognitive empathy is the ability to know and distinguish the emotional state of others without experiencing emotional transmission [67-69].

Previous studies have consistently shown a relationship between empathy and antisocial behavior, bullying, and cyberbullying - regardless of the type of bullying and gender of the actors [70, 71]. Specifically, adolescents with poor empathy are more often involved in bullying. In contrast to face to face bullying, cyberbully perpetrators cannot see the reaction of the victim's distress because it occurs in the context of anonymity. Existing empirical findings indicate that empathy is a predictor of cyberbullying perpetration $[72,73]$. Empathy also influences the possibility of online 'bystanders' becoming involved in cyberbullying [74-76]. Schultze-Krumbholz and Scheithauer [77] found that both actors and victims of cyberbullying showed low levels of empathy compared to adolescents who are not involved in cyberbullying. Some of the studies above confirm the role of empathy on cyberbullying behavior. Current research will reexamine this relationship in Indonesian adolescents to strengthen the theoretical consistency.

This study aimed to examine whether positive parent-child relationships, happiness, empathy, and school climate encourage cyberbullying behavior among adolescents. Based on the literature, the above variables have only been recently studied. Given the limited research on Indonesian adolescents, it is relevant to have more predictive studies to explain which factors may lead to perpetrators of cyberbullying.

\section{RESEARCH METHOD}

\subsection{Participants}

There were 112 students (median age $=15, \mathrm{SD}=1.34)$, comprising of junior $(\mathrm{n}=68)$ and senior high school students $(n=44)$, participated in this study. Within this sample, 65 participants were female while the remaining participants are males $(n=47)$. The researcher employed simple random sampling to recruit the participants. Respondents came from three junior and senior high schools in Kulonprogo district, Indonesia.

\subsection{Measurement}

\subsubsection{Cyberbullying}

Nine items of perpetrator cyberbullying scale were constructed based on Willard [78] seven forms of cyberbullying namely: Flaming (online fights using electronic messages with angry and vulgar language), online harassment (repeatedly sending nasty, mean, and insulting messages), cyberstalking (repeated, intense harassment and denigration that includes threats or creates significant fear), denigration ("dissing" someone online. Sending or posting gossip or rumors about aperson to damage his or her reputation or friendships), masquerade/impersonation (pretending to be someone else and sending or posting material to get that person in trouble or danger or to damage that person's reputation or friendships), outing (sharing someone's secrets or embarrassing information or images online., and exclusion (intentionally and cruelly excluding someone from an online group). A higher score on the perpetrator cyberbullying scale indicates higher cyberbullying conducted by perpetrators. Each item has four alternative answers: frequently, occasionally, rarely and never. The scale consists of favorable and unfavorable responses. For the favorable response, the scores are given as such: frequently (4), occasionally (3), rarely (2), and never (1). Meanwhile, scores for the unfavorable response are given as such: never (1), rarely (2), occasionally (3), and frequently (4). Item examples include "I accidentally sent insulting words to someone's social media account", "I send indecent images to someone's social media account", and "I posted someone's personal secret on my social media account". The internal consistency reliability test shows a satisfactory result (Cyberbullying $\alpha=.862$ ).

\subsubsection{Empathy}

Empathy was assessed using the Eight Question Empathy scale (EQ-8), the scale has 8 items [79]. The EQ-8 assesses cognitive empathy, emotional reactivity, and social skills. A higher score on the EQ-8 indicates higher empathy. Responses to a 4-point scale ranging from Strongly Agree (1) to Strongly Disagree (4) (eg "I can feel what others are feeling." "When I see other people in distress, I feel like I help ease the burden." "I don't care about the feelings of others"). For the empathy scale, has an item-total correlation 
ranges from $445-775$. The internal consistency reliability test with Cronbach alpha shows a satisfactory result (Empathy $\alpha=.883$ ).

\subsubsection{Parent-child relationship}

The parent-child relationship was assessed using the adapted 14-item scale which originated from the Inventory of Parent and Peer Attachment (IPPA) by Armsden \& Greenberg [80]. A higher score on the IPPA indicates more positive parent-child relationship. This scale was later modified by Vignolli \& Mallet [81]. Responses are given on a 4-point scale ranging from $1=$ Strongly Agree; to $4=$ Strongly Disagree. (e.g., "my parent support me", "I can communicate openly with my parent", "I feel detach from my parent", "I have a long dispute with my parents"). The parent-child relationship scale has hasa item-total correlation ranges from .510-.791. The internal consistency reliability test with Cronbach alpha showsa satisfactory result (Parent-child relationship $\alpha=.851$ ).

\subsubsection{Happiness}

The happiness scale was assessed and adapted by Hills \& Argyle [82]. A higher score on the happiness scale indicates higher happiness level. There are 15 statements (e.g., "I intensely care about other people," "I feel that life is very boring," "I have very warm feelings towards almost everyone," "I feel happy in general"). Participants were asked to indicate how much they agree or disagree to each statement througha 4-point response format ranging from Strongly Agree (1) to Strongly Disagree (4). The happiness scale has an item-total correlation ranges from .297-.697. The internal consistency reliability test with Cronbach alpha showsa satisfactory result (happiness $\alpha=.902$ ).

\subsubsection{School climate}

School climate was assessed using the School Climate Survey (SCS) which measure fairness, order and discipline, student-teacher relations, and achievement motivation [83]. A higher score on the SCS indicates more positive school climate. Participants were asked to indicate their answer in a 4-point response format ranging from Strongly Agree (1) to Strongly Disagree (4) (e.g., "at my school, boys and girls are treated equally well", "Some children carry guns or knives to my school", "My teachers make me feel good about myself", "I like coming to school"). The school climate scale has an item-total correlation ranges from .320 to .744 . The internal consistency reliability test with Cronbach alpha showsa satisfactory result (school climate $\alpha=.901)$.

\subsubsection{Procedure}

Data was collected from three schools by first asking for permission from the school. Data was collected in the classroom. All students completedinformed consent and understood that involvement in this research is voluntary without coercion. Next, an assistant researcher briefed the students about the subject of this research, how to fill in the scales, and explained the anonymity in filling the scale. In addition, the research assistant also explained the confidentiality issue of this study. Students also received an explanation that there is no right or wrong answers. They were encouraged to choose the answers that best reflect their current condition. It took approximately 35 minutes to fill-in the measurement tools.

\subsubsection{Data analysis}

Linear regression analysis was used to test the hypotheses of this study. Additionally, descriptive analysis was employed to explore the participants' demographic data. Tests for normality, linearity, multicollinearitywere also carried out to ensure that data meets its parametric assumptions.

\section{RESULTS AND DISCUSSION}

The results of this study indicate that school climate has a role in cyberbully behavior $(\beta=-.251, \mathrm{p}=$ $.010)$. Likewise, parent-child relationship $(\beta=-.257, p=.004)$, empathy $(\beta=-.179, p=.050)$, and happiness $(\beta=-.168, p=.051)$ also encourage cyberbullying behavior. Table 1 describes the regression analysis results.

Meanwhile, Table 1 depicts the mean, standard deviation, and correlation between variables. School climate has a negative significant correlation with cyberbullying behavior. Happiness also has a negative significant correlation with cyberbullying behavior. Empathy has a negative significant correlation with cyberbullying behavior. Parent-child relations have a negative significant correlation with cyberbullying behavior. Table 2 shows the regression analysis of school climate, happiness, parent-child relationships, and empathy for cyberbullying. 
Table 1. Means, standard deviations, and intercorrelations between variables

\begin{tabular}{cccccccc}
\hline Measures & $\mathrm{M}$ & $\mathrm{SD}$ & 1 & 2 & 3 & 4 & 5 \\
\hline Cyberbullying & 30 & 4.6 & 1.000 & - & - & - & - \\
School climate & 32.9 & 4.3 & $-.474^{*}$ & 1.000 & & - & - \\
Happiness & 26.9 & 3. & $-.331^{*}$ & $.351^{*}$ & 1.000 & - & - \\
Parent-child relation & 29.2 & 4.2 & $-.442^{*}$ & $.275^{* *}$ & $.248^{* *}$ & 1.000 & - \\
Empathy & 31.6 & 3.7 & $-.392^{*}$ & $.399^{*}$ & .020 & $.376^{*}$ & .1 .000 \\
\hline$* \mathrm{p}<.01, * * \mathrm{p}<.05$ & & & & & & &
\end{tabular}

Table 2. The regression analysis of school climate, happiness, parent-child relationships, school antibullying, empathy for cyberbullying

\begin{tabular}{cccccc}
\hline Variables & $B$ & $S E B$ & $\beta$ & $t$ & $p$ \\
\hline School climate & .275 & .105 & -.251 & 2.624 & .010 \\
Happiness & .228 & .115 & -.168 & 1.976 & .051 \\
Parent-child relation & .287 & .096 & -.257 & 2.985 & .004 \\
Empathy & .223 & .113 & -.179 & 1.984 & .050 \\
\hline Note. Adjusted $R^{2}=.343(N=312, p=.000)$. & &
\end{tabular}

This study examined whether parent-child relationships, happiness, empathy, and school climate encourage cyberbullying behavior among adolescents. The results of this study indicate that all proposed hypotheses are accepted. More specifically, the results of this study found a significant relationship between empathy and cyberbullying behavior. The results of this study are also in accordance with Festl'sstudy which found a significant relationship between empathy and cyberbullying [84]. Likewise, Del Rey's research results confirmed the same results [85]. This study shows that the findings are in accordance to previous studies, notably that empathy correlates with cyberbullying behavior [24, 86]. The relationship between empathy and cyberbullying is also consistent with previous traditional bullying studies [87-89].

Furthermore, this study presents arguments despite important differences between the contexts in which intimidation and aggression occur; the results of this study indicate that people who conduct cyberbullying display a lack of empathy similar to traditional bullying [71]. Cognitive and affective empathy can influence social interaction, while affective empathy seems to be an essential factor in shaping and encouraging bullying behavior. Future research should investigate this relative role of cognitive and affective empathy in cyberbullying behavior. Empathy based on some previous studies is also shown to havea strong relationship with antisocial behavior.

This study also illustrates a significant relationship between school climate and cyberbullying behavior. These results corroborate the findings of Låftman, Ostberg \& Modin [89] who found positive school leadership to be related to a low frequency of cyberbullying/cyber victimization behavior in schools. Some previous studies have found a connection between various school-contextual characteristics and traditional forms of intimidation [90]. Traditional bullying has been shown to occur less frequently in schools, characterized by traits such as clear rules, positive student-teacher relations, attitudes of teachers who are against intimidation as well as their intervention for it [85, 91-95] in their study of teachers and students in Norway found that schools that assessed their teachers about school leadership, teacher affiliation, and high collaborative activities showed lower rates of victims and perpetrators bullying. The research by Acosta, et al. [96] found that students in positive school climates reported experiencing fewer physical and emotional abuse, as well as cyberbullying behaviors. They also report high levels of school connectedness, peer attachment, assertiveness, and empathy. Research by Farina [97] found that positive school climate predicts bullying incidence. Eliot et al [98] found that students who perceived having supportive teachers and school staff members are more likely to have a positive attitude towards help-seeking for bullying and threats of violence. In addition, other studies show that students' perception of the school climate is positively correlated with student adjustment, academic achievement, and commitment to learning [99, 100], including school safety and teacher victimization [101, 102].

This study also found a significant relationship between parent-child relationships and cyberbullying behavior. The study from Navarro et al [21] confirms the same results in which parental mediation in the use of the internet decreases the incidence of cybervictimization. Larrañaga et al [103] study also confirms that adolescents with a type of avoidance communication with their mothers are associated more with cyberbullying victimization. In addition, it was also found that adolescents who have avoidant communication andhigh sense of loneliness are associated with severe cyberbullying victimization, and individuals who have the offensive type of communication correlate with severe cyberbullying victimization. These results indicate the importance of communication within the family in preventing cyberbullying 
victimization. The study of Estéévez, Murgui, Musitu, \& Moreno [104] confirms that a positive family environment is characterized by adequate social support, strong cohesiveness among family members, and an open and empathic communication. Thiscommunication contribute to preventing adolescents from engaging in cyberbullying behavior or becoming victims of cyberbullying. Conducive family condition facilitates children to develop adequate social adjustment, and establish positive relationships with their peers. Furthermore, previous research shows that family environment positively influences children's adherence to social rules, which is directly related to school violence [105]. In addition, high family conflict acts as a risk factor for being bullied via digital social media, and victims of cyberbullying have families that are less cohesive and open than non-victims of cyberbullying [106].

Contradicly, this study found not significant positive relationship between happiness and cyberbullying behavior. These results contradict with Qodir, Diponegoro \& Safaria study [107] which states that there is a relationship between happiness and cyberbullying behavior. Additionally, Ali Padir, Eroglu, \& Caliskan [55] also showed difference result Furthermore, the study of Navarro et al [56] found a decrease in happiness in both perpetrators and victims of cyberbullying. The link between happiness and prosocial behavior into the Broaden-and-Build Theory [57], which posits that, experiences positive emotions broad people perspectives and actions and builds enduring biopsychosocial resources and relationships.

Although current research provides new insights related to the relationship between parent-child relationship, happiness, empathy and school climate with cyberbullying behavior, there are several limitations of this study that should be considered. First, the cross-sectional design of this study cannot produce the establishment of causality between different variables; therefore, longitudinal studies are recommended for future studies. Secondly, the participants in this study only consisted of three schools from a specific region in Yogyakarta, Indonesia, so it is suggested that future research use a broader and more representative sample to ensure arobust and reliable result. Thirdly, this study uses self-reported measures, which although effective and reliable in collecting data, can be influenced by response bias (faking good or faking bad).

Despite these limitations, the results of this study are of particular relevance given that they highlight factors that affect the cyberbullying problem among Indonesian adolescents. These are variables that have yet to receive much attention from the scientific field. Thus, the parent-child relationship, school climate, empathy, and happiness are seen to play an important role as a protective factor from cyberbullying. Similarly, all of the previously mentioned variables act as a protective factor against students becoming victims as well as aggressors. Thus, it is corroborated that all variables should be taken into consideration when developing social and educational policies as well as prevention and intervention programs to alleviate this problem.

\section{CONCLUSION}

The results of this study show that parent-child relationship, empathy, happiness, and school climate has a negative significant relationship with cyberbully behavior. The suggestion for further research is to add other variables that are hypothesized to play a role in the occurrence of cyberbullying. Taking into consideration the low representativeness of the sample, future studies are advised to consider using a larger number of samples to improve the representativeness of current population.

\section{ACKNOWLEDGEMENTS}

Thank to Universitas Ahmad Dahlan that have provided a grant for this research. We also send our thankfulness to Rector of Universitas Ahmad Dahlan for his support of this research.

\section{REFERENCES}

[1] S.G. Handono, K. Laeheem, and R. Sittichai, "Factors related with cyberbullying among the youth of Jakarta, Indonesia," Children and Youth Services Review, vol. 99, pp. 235-239, Apr 2019.

[2] R. Kowalski, S.P. Limber, and A. McCord, "A developmental approach to cyberbullying: Prevalence and protective factors. Aggression and Violent Behavior," Aggression and Violent Behavior, vol. 45, pp. 20-32, 2019.

[3] T. Safaria, "Prevalence and impact of cyberbullying in a sample of Indonesian junior high school students," TOJET: The Turkish Online Journal of Educational Technology, vol. 15, no. 1, pp. 82-91, 2016.

[4] R. S. Tokunaga, "Following you homefrom school: acritical review and synthesis of research on cyberbullying victimization," Computers in Human Behavior, vol. 26, no. 3, pp. 277-287, 2010.

[5] R. Graham, and F. Wood, "Associations between cyberbullying victimization and deviant health risk behaviors," The Social Science Journal, vol. 56, no. 2, pp. 183-188, 2019.

[6] J. Brailovskaia, T. Jeismann, and J. Margraf, "Cyberbullying, positive mental health and suicide ideation/behavior," Psychiatry Res., vol. 267, pp. 240-242, Sep 2018. 
[7] T.N. Beran, et al, "Evidence for the need tosupport adolescents dealing with harassment and cyber-harassment: Prevalence, progression, and impact," School Psychology International, vol. 33, no. 5, pp. 562-576, 2012.

[8] C.S, Bhat, "Cyber bullying: Overview and strategies for school counsellors, guidance officers, and all school personnel," Australian Journal of Guidance and Counselling, vol. 18, no. 1, pp. 53-66, 2008.

[9] A.T. Glasner, "On the front lines: Educating teachers about bullying andprevention methods," Journal of Social Sciences, vol. 6, no. 4, pp. 537-541, 2010.

[10] A. M Schenk, and W.J. Fremouw, "Prevalence, psychological impact, andcoping of cyberbully victims among college students," Journal of School Violence, vol. 11, no. 1, pp. 21-37, 2012.

[11] M. Wong-lo, L.M. Bullock, and R.A. Gable, "Cyber bullying: Practices to facedigital aggression," Emotional and Behavioural Difficulties, vol. 16, no. 3, pp. 317-325, 2011.

[12] E.M. Selkie, et al, "Cyberbullying, depression, and problem alcohol use in female college students: A multisite study," Cyberpsychology, Behavior, and Social Networking, vol. 18, no. 2, pp 79-86, 2015.

[13] Schneider, S.K., et al, "Cyberbullying, schoolbullying, and psychological distress: A regional censusof high school students," American Journal of PublicHealth, vol. 102, no. 1, pp. 171-177, 2012.

[14] Y. Akbulut, and C. Cuhadar, "Reflections of Preservice Information Technology Teachers Regarding Cyberbullying," Turkish Online Journal of Qualitative Inquiry, vol. 2, no. 3, pp. 67-76, 2011

[15] B. Spears, and P. Slee, L. Owens and B. Johnson, "Behind the scenes and screens: Insights into the human dimension of covert and cyberbullying," Journal of Psychology, vol. 217, no. 4, pp. 189-196, 2009.

[16] J. Riddell, D. Pepler, and W. Craig, "Cyberbullying in Canada," In A. Baldry, C. Blaya, \& D. P. Farrington (Eds.), To be published by Palgrave McMillan: Palgrave Studies in Cybercrime and Cybersecurity Series, pp. 39-63, 2018.

[17] H, Ganey, and D.P Farrington, D. P. "Cyberbullying in the United Kingdom and Ireland,” In A. Baldry, C. Blaya, \& D. P. Farrington (Eds.). To be published by PalgraveMcMillan: Palgrave Studies in Cybercrime and Cybersecurity Series, pp. 101-143, 2018.

[18] D.L. Espelage, J.S. Hong, and A. Valido, "Cyberbullying in the United States," In A. Baldry, C. Blaya, \& D. P. Farrington (Eds.), To be published by Palgrave McMillan: Palgrave Studies in Cybercrime and Cybersecurity Series [in press], pp. 39-63, 2018.

[19] M. Herrera-López, E.M. Romera, E. M, and R. Ortega-Ruiz, "Bullying cyberbullying enLatino américa," Revista Mexicana de InvestigaciónEducativa, vol. 23, no. 76, pp. 125-155, 2018.

[20] I, Zych, R. Ortega-Ruiz, R., and I. Marín-López, "Cyberbullying: A systematic review ofresearch, its prevalence and assessment issues in Spanish studies," PsicologíaEducativa, vol. 22, no. 1, pp. 5-18, 2016.

[21] R. Navarro, C. Serna, V. Martínez, and R. Ruiz-oliva, R., "The role of Internet use and parental mediation on cyberbullying victimization among Spanish children from rural public schools," European Journal Psychological Education, vol. 28, pp. 725-745, 2013.

[22] C. Lee, and N. Shin, "Prevalence of cyberbullying and predictors of cyberbullying perpetration among Korean adolescents," Computers in Human Behavior, vol. 68, pp. 352-358, Mar 2017.

[23] T. Heiman, and D. Olenik-Shemesh, "Computer-based communication and cyberbullying involvement in the sample of Arab teenagers," Education and Information Technol, vol. 21, no. 5, pp. 1183-1196, 2015.

[24] B.P. Ang and D.H. Goh, "Cyberbullying among adolescents: The role of affective and cognitive empathy, and gender," Child Psychiatry \& Human Development, vol. 41, no. 5, pp. 387-397, 2010.

[25] R. Udris, "Cyberbullying in Japan: An exploratory study," International Journal of Cyber Society and Education, vol. 8, no. 2, pp. 59-80. 2015.

[26] G.T. Harold and L.D. Leve. "Parents as partners: How the parental relationship affects children's psychological development," In How Couple Relationships Shape our World Clinical Practice, Research, and Policy Perspectives. Taylor \& Francis Publication, pp. 32-43, 2018.

[27] M.C. Martínez-Monteagudo, et al, "Cyberbullying in the university setting. Relationship with family environment and emotional intelligence," Computers in Human Behavior, vol. 91, pp. 220-225, Feb 2019.

[28] M.L. Ybarra, and K.J. Mitchell, "Online aggressor/targets, aggressors, and targets: A comparison of associated youth characteristics," Journal of Child Psychology andPsychiatry, vol. 45, no. 7, pp. 1308-1316, 2004.

[29] J.D. Hawkins, T.I. Herrenkohl, D.P. Farrington, D. Brewer, R.F. Catalano, T.W. Harachi, et al., Predictors of youth violence, Washington DC: The Office of Juvenile Justice and Delinquency Prevention, 2000.

[30] I. Tanrikulu and M. Campbell, "Correlates of traditional bullying and cyberbullying perpetration among Australian students," Children and Youth Services Review, vol. 55, pp. 138-146, Aug 2015.

[31] F. Gómez-Franco and J.C. Sendin, "Internet comorefugio y escudo social: Usosproblemáticos de la red porjóvenesespañoles [Internet as a haven and social shield. Problematic uses of the network by young Spaniards]," Comunicar, vol. 43, pp. 45-53, 2014.

[32] De la Torre, M., García, Villa, M., and Casanova, P., "Relaciones entre violencia escolar yautoconcepto multidimensional en adolescentes de EducaciónSecundariaObligatoria [Relationships between school violence and multidimensional self-concept: Teenagers from the Obligatory Secondary Education]," European Journal of Education and Psychology, vol. 1, no. 2, pp. 57-70, 2008.

[33] J. Cohen, E.M. McCabe, N.M. Michelli, and T. Pickeral, "School climate: Research, policy, practice, and teacher education," Teachers College Record, vol. 111, no. 1, pp. 180-213, 2009.

[34] M.D. Shakeel, and C.A. DeAngelis, "Can private schools improve school climate? Evidence from a nationally representative sample," Journal of School Choice, vol. 12, no. 3, pp. 426-445, 2018.

[35] K.J. Zullig, T.M, Koopman, T. M, J.M. Patton, and V.A. Ubbes, "School climate: Historical review, instrument development, and school assessment," Journal of Psychoeducational Assessment, vol. 28, no. 2, pp. 139-152, 2010. 
[36] G.A. Donaldson, How leaders learn: Cultivating capacities for school improvement, New York: Teachers College Press, 2008.

[37] S.M. Hord, and W.A. Sommers, Leading professional learning communities: Voices from research and practice, CA: Corwin Press, 2018.

[38] A.A. Payne, et al, "Schools as communities: Therelationships among communal school organization, student bonding, and school disorder," Criminology, vol 41, no. 3, pp. 749-778, 2003.

[39] E. Stewart, "School social bonds, school climate, and school misbehavior: A multilevelanalysis," Justice Quarterly, vol. 20 , no. 3 , pp. $575-604,2003$.

[40] A. Thapa, J. Cohen, S. Guffey, and A. Higgins-D’Alessandro, "A review of school climate research," Review of Educational Research, vol. 83, no. 3, pp. 357-385.2013.

[41] N.K. Bowen, and G.L. Bowen, "Effects of crime and violence in neighborhoods and schools on the school behavior and performance of adolescents," Journal of Adolescent Research, vol. 14, no. 3, pp. 319-42, 1999.

[42] J. Burdick-Will, "School violent crime and academic achievement in Chicago," Sociology of Education, vol. 86, no. 4, pp. 346-361, 2013

[43] D.U. Patton, et al, "Exposure to violence, student fear, and low academic achievement: African American males in the critical transition to high school," Children and Youth Services Review, vol. 34, no. 2, pp. 88-95. 2012.

[44] M. Janosz, I. Archambault, L.S. Pagani, S. Pascal, A.J.S. Morin, and F. Bowen, "Are there detrimental effects of witnessing school violence in early adolescence?” Journal of Adolescent Health, vol. 43, no. 6, pp. 600-608, 2008.

[45] L. Arseneault, L. Bowes, L and S. Shakoor, "Bullying victimization in youths and mental health problems: Much a do about nothing?" Psychological Medicine, vol. 40, no. 5, pp. 717-729, 2010.

[46] Chen, G., "School disorder and student achievement: A study of New York city elementary schools," Journal of School Violence, vol. 6, no. 1, pp. 27-43, 2007.

[47] J. Juvonen, J, Y. Wang, and G. Espinoza, G, "Bullying experiences and compromised academic performance across middle school grades," Journal of Early Adolescence, vol. 31, no. 1, pp. 152-173, 2011.

[48] N. Park, and C. Peterson, "Character strengths and happiness among young children: Content analysis of parental descriptions," Journal of Happiness Studies, vol. 7, no. 3, pp. 323-341, 2006.

[49] C. Peterson, W. Ruch, U. Beermann, N. Park, and M.E.P. Seligman, "Strengths of character, orientations to happiness, and life satisfaction,” The Journal of Positive Psychology, vol. 2, no. 3, pp. 149-156, 2007.

[50] L.B. Aknin, T. Broesch, J.K. Hamlin, and J.W. Van de Vondervoort, J. W., "Prosocialbehavior leads to happiness in a small-scale rural society," Journal of Experimental Psychology: General, vol. 144, no. 4, pp. 788-795, 2015.

[51] K. Otake, S. Shimai, J. Tanaka-Matsumi, K. Otsui and B. L. Fredrickson, "Happy people become happier through kindness: A counting kindnesses intervention,” Journal of Happiness Studies, vol. 7, no. 3, pp. 361-375, 2006.

[52] Bakker, A. B., Westman, M., and van Emmerik, H. I. J., "Advancements in crossover theory" Journal of Managerial Psychology, vol. 24, no. 3, pp. 206-219, 2009.

[53] S. Erreygers, et al, "Feel Good, Do Good Online? Spillover and Crossover Effects of Happiness on Adolescents' Online Prosocial Behavior," Journal of Happiness Studies, vol. 20, no. 4, pp. 1241-1258, 2019.

[54] L. Uusitalo-Malmivaara, and J.E. Lehto, "Happiness and depression in the traditionally bullied and cyberbullied 12-year-old," Open Review of Educational Research, vol. 3, no. 1, pp. 35-5, 2016.

[55] M. Ali Padir, Y. Eroglu, and M. Çaliskan, "The investigation of relationships between subjective happiness, cyber bullying, and cyber victimization in adolescents," Online Journal of Technology Addiction \&Cyberbullying, vol. 2, no. 1 , pp. 32-35, 2015.

[56] R. Navarro, R. Ruiz-Oliva, E. Larrañaga, and S. Yubero, S., "The impact of cyberbullying and social bullying on optimism, global and school-related happiness and life satisfaction among 10-12-year-old school children," Applied Research in Quality of Life, vol. 10, no. 1, pp. 15-36, 2015.

[57] A.B. Bakker, E. Demerouti, and R. Burke, "Workaholism and relationship quality: A spillover-crossover perspective," Journal of Occupational Health Psychology, vol. 14, no. 1, pp. 23-33, 2009.

[58] K.M. Lawson, K.D. Davis, S.M. McHale, L.B. Hammer, and O.M. Buxton, "Daily positive spillover and crossover from mothers' work to youth health," Journal of Family Psychology, vol. 28, no. 6, pp. 897-907, 2014.

[59] A. Rodríguez-Muñoz, A. I. Sanz-Vergel, E. Demerouti, and A.B. Bakker, "Engaged at work and happy at home: A spillover-crossover model," Journal of Happiness Studies, vol. 15, no. 2, pp. 271-283, 2014.

[60] N. Eisenberg, am J. Strayer, J., Empathy and its development, Cambridge: Cambridge University Press, 1987.

[61] D. Cohen, and J. Strayer, "Empathy in conduct-disordered and comparisonyouth," Developmental Psychology, vol. 32, no. 6, pp. 988-998, 1996.

[62] N. Eisenberg, C.L. Shea, G. Carlo, and G.P. Knight, "Empathy-related responding and cognition: A 'chicken and the egg' dilemma," In W. M. Kurtines (Ed.), Handbook of moral behavior and development: vol. 2, Research Hillsdale, NJ: Erlbaum, pp. 63-88, 1991.

[63] M.H. Davis, M. H, Empathy: A social psychological approach, Madison: Brown \&Bench-Mark Publishers, 1994.

[64] N.D. Feshbach, "Parental empathy and child adjustment/maladjustment," In N. Eisenberg \& J. Strayer (Eds.), Empathy and its development, New York: CUP. 1987.

[65] N. Eisenberg, and P. Miller. Empathy, sympathy, and altruism: Empirical andConceptual links. In N. Eisenberg \& J. Strayer (Eds.), Empathy and its development, New York: CUP, pp. 292-316, 1987.

[66] L. Penner, J. Dovidio, J. Piliavin, and D. Schroeder, "Prosocial behavior: Multilevel perspectives," Annual Review of Psychology, vol. 56, pp. 365-392, 2005.

[67] D. McIllwain, "Bypassing empathy: A Machiavellian theory of mind andsneaky power. In B. Repacholi, \& V. Slaughter (Eds.)," Individual differences intheory of mind, Macquarie monographs in cognitive science, Sussex: Psychology Press, pp. 39-66, 2003. 
[68] I. Dziobek, et al, "Dissociation of cognitive and emotional empathy in adults with AspergerSyndrome using the Multifaceted Empathy Test (MET)," Journal of Autism andDevelopmental Disorders, vol. 38, no. 3, pp. 464-473, 2008.

[69] Z. Schechtman, "Cognitive and affective empathy in aggressive boys: Implications for counselling," International Journal for the Advancement of Counselling, vol. 24, no. 4, pp. 211-222, 2002.

[70] E. Ciucci, and A. Baroncelli, "The emotional core of bullying: Further evidences of the role of callous-unemotional traits and empathy," Personality and Individual Differences, vol. 67, pp. 67-74, Sep 2014.

[71] D. Jolliffe, and D.P. Farrington, "Examining the relationship between low empathy and bullying," Aggressive Behavior, vol. 32, no. 6, pp. 540-550, 2006.

[72] J.A. Casas, R. Del Rey, and R. Ortega-Ruiz, "Bullying and cyberbullying: Convergent and divergent predictor variables," Computers in Human Behavior, vol. 29, no. 3, pp. 580-587, 2013.

[73] G. Steffgen, et al, "Are cyberbullies lessempathic? Adolescents' cyberbullying behavior and empathic responsiveness," Cyberpsychology, Behavior and Social Networking, vol. 14, no. 11, pp. 643-648, 2011.

[74] J. Barlinska, et al. "Cyberbullying among adolescentbystanders: Role of the communication medium, form of violence, andempathy," Journal of Community and Applied Social Psychology, vol. 23, no. 1, pp. 37-51, 2013.

[75] C.M. Kokkinos, et al, "Cyber-bullying: Aninvestigation of the psychological profile of university student participants," Journal of Applied Developmental Psychology, vol. 35, no. 3, pp. 204-214, 2014.

[76] J.L. Pettalia, E. Levin, and J. Dickinson, "Cyberbullying: Eliciting harm withoutconsequence," Computers in Human Behavior, vol. 29, pp. 2758-2765, 2013.

[77] A. Schultze-Krumbholz, and H. Scheithauer, H., "Social-behavioral correlates ofcyberbullying in a German student sample," Zeitschrift fur Psychologie/Journal of Psychology, vol. 217, no. 4, pp. 224-226, 2009.

[78] N. Willard, Educator's Guide to Cyberbullying and Cyberthreats, 2007. [Online]. Available: http://csriu.org; http://cyberbully.org; and http://cyber-safe-kids.com

[79] L.J. Loewen, et al., An eight-item form of the Empathy Quotient (EQ) and an application to charitable giving, 2010. [Online]. Available: http://crcee.umontreal.ca/pdf/Eight\%20Question\%20ES_final.pdf

[80] G.C. Armsden and M.T. Greenberg, "The inventory of parent and peer attachment: Individual differences and their relationship to psychological well-being in adolescence," Journal of Youth and Adolescence, vol. 16, no. 5, pp. 427-454, 1987.

[81] E. Vignoli and P. Mallet, "Validation of a brief measure of adolescents' parent attachment based on Armsden and Greenberg's three-dimension model," European Review of Applied Psychology/Revue Européenne de Psychologie Appliquée, vol. 54, no. 4, pp. 251-260, 2004.

[82] P. Hills, and M. Argyle, "The Oxford Happiness Questionnaire: a compact scale for the measurement of psychological well-being," Personality and Individual Differences, vol. 33, no. 7, pp. 1073-1082, 2002.

[83] N.M. Haynes, C. Emmons, and M. Ben-Avie, M, "School climate as a factor in student adjustment and achievement," Journal of Educational \& PsychologicalConsulting, vol. 8, no. 3, pp. 321-329, 1997.

[84] R. Festl, "Perpetrators on the internet: Analyzing individual and structural explanation factors of cyberbullying in school context," Computers in Human Behavior, vol. 59, pp. 237-248, Jun 2016.

[85] R. Del Rey, L. Lazuras, J.A. Casas, V. Barkoukis, R. Ortega-Ruiz, and H. Tsorbatzoudis, "Does empathy predict (cyber) bullying perpetration, and how do age, gender and nationality affect this relationship?" Learning and Individual Differences, vol. 45, pp. 275- 281, Jan 2016.

[86] G. Brewer, and J. Kerslake, "Cyberbullying, self-esteem, empathy and loneliness," Computers in Human Behavior, vol. 48, pp. 255-260, Jul 2015.

[87] D. Joliffe, and D.P. Farrington, "Is low empathy related to bullying after controlling for individual and social background variables?" Journal of Adolescence, vol. 34, no. 1, pp. 59-71, 2011.

[88] K.M. Merrell, B.A. Gueldner, S.W. Ross, and D.M. Isava, "How effective are school bullying intervention programs? A meta-analysis of intervention research," School Psychology Quarterly, vol. 23, no. 1, pp. 26-42, 2008.

[89] S.B. Låftman, B Modin, and V. Östberg, "School climate and exposure to bullying: A multilevel study," Sch. Eff. Sch. Improv, vol. 28, no. 1, pp. 153-164, 2017.

[90] A. Laurito, et al, "School Climate and the Impact of Neighborhood Crime on Test Scores," RSF The Russell Sage Foundation Journal of the Social Sciences, vol. 5, no. 2, pp. 141-166, 2019.

[91] S. Saarento, A. Kärnä, E.V.E. Hodges, and C. Salmivalli, "Student-classroom and school-level risk factors for victimization," Journal of School Psychology, vol. 51, no. 3, pp. 421-434, 2013.

[92] S. Saarento, C.F. Garandeau, and C. Salmivalli, "Classroom and school-level contributions to bullying and victimization: A review," J. Community Appl. Sch. Psychol, vol. 25, no. 3, pp. 204-218, 2015.

[93] C.M. Azeredo, et al., "School bullying: A systematic review of contextual-level risk factors in observational studies," Aggression Violancee Behavior, vol. 22, pp. 65-76, May-Jun 2015.

[94] E. Roland, and D. Galloway, "Professional cultures in schools with high and low rates of bullying," Sch. Eff. Sch. Improv, vol. 15, no. 3-4, pp. 241-260, 2004.

[95] S.K. Ertesvåg, and E. Roland, "Professional cultures and rates of bullying" Sch. Eff. Sch. Improv, vol. 26, no. 2, pp. 195-214, 2015.

[96] J. Acosta, et al, "Understanding the relationship between perceived school climate and bullying: A mediator analysis," Journal of School Violence, vol. 18, no. 2, pp. 200-215, 2019.

[97] K.A. Farina, "Promoting a Culture of Bullying: Understandingthe Role of School Climate and School Sector," Journal of School Choice, vol. 13, no. 1, pp. 94-120, 2019. 
[98] M. Eliot, D. Cornell, Anne Gregory, and X. Fan, "Supportive school climate and student willingness to seek help for bullying and threats of violence," Journal of School Psychology, vol. 48, no. 6, pp. 533-553, 2010.

[99] S. Brand, R.D. Felner, M.S. Shim, A. Seitsinger, and T. Dumas, "Middle school improvement and reform: Development and validation of a school-level assessment of climate, cultural pluralism, and school safety," Journal of Educational Psychology, vol. 95, no. 3, pp. 570-588, 2003.

[100] M. Phillips, "What makes schools effective? A comparison of the relationships of communitarian climateand academic climate to mathematics achievement and attendance during middle school," American Educational Research Journal, vol. 34, no. 4, pp. 633-662, 1997.

[101] R.A. Astor, et al, 'School climate, observed risky behaviors, andvictimization as predictors of high school students' fear and judgments of school violence as a problem," Health Edu. \& Behavior, vol. 29, no. 6, pp. 716-736, 2002.

[102] G.D. Gottfredson, D.C. Gottfredson, A.A. Payne, and N.C. Gottfredson, "School climate predictors of school disorder: Results from a national study of delinquency prevention in schools," Journal of Research in Crime and Delinquency, vol. 42, no. 4, pp. 412-444, 2005.

[103] E. Larrañaga, S.Yubero, A.Ovejero, and R. Navarro, "Loneliness, parent-child communication and cyberbullying victimization among Spanish youths," Computers in Human Behavior, vol. 65, pp. 1-8, Dec 2016.

[104] E. Estévez, S. Murgui, G. Musitu, and D. Moreno, "Adolescent aggression: Effects of gender and family and school environments," Journal of Adolescence, vol. 31, no. 4, pp. 433-450, 2008.

[105] M.G. López-Pérez, "Influencia del clima escolar y familiar en el acoso escolar ycibernético de universitarios [Influence of school and family climate on bullying andcyberbullying of university students]," Revista Mexicana de Investigación enPsicología, vol. 9, no. 1, pp. 31-44, 2017.

[106] J. Ortega-Barón, S. Buelga, and M.J. Cava, M. J, "Influenciadelclima escolar y familiarenadolescentes, víctimas de ciberacoso [The influence of school climate and familyclimate among adolescents' victims of cyberbullying]," Comunicar, vol. 46, pp. 57-65, 2016.

[107] A. Qodir, A.M. Diponegoro, and T. Safaria, "Cyberbullying, happiness, and style of humor among perpetrators: is there a relationship?" Humanities \& Social SciencesReviews, vol. 7, no. 3, pp. 200-206, 2018. 